\title{
Management Share Proprietory and Firm Value: Are There Peculiar Determinants?
}

\author{
George William Lokko*, Yang Li, Francis Atta Sarpong ${ }^{\circledR}$, Larsey Naphtali Akwetteh \\ School of Economics and Management, Anhui University of Science and Technology, Huainan, China \\ Email: *lokkogeorge@gmail.com, y321212@163.com, francis.sarpong@stu.ucc.edu.gh, nlarsey.nl@gmail.com
}

How to cite this paper: Lokko, G. W., Li, Y., Sarpong, F. A., \& Akwetteh, L. N. (2021). Management Share Proprietory and Firm Value: Are There Peculiar Determinants? Open Journal of Business and Management, 9, 2653-2673.

https://doi.org/10.4236/ojbm.2021.96146

Received: September 20, 2021

Accepted: October 18, 2021

Published: October 21, 2021

Copyright $\odot 2021$ by author(s) and Scientific Research Publishing Inc. This work is licensed under the Creative Commons Attribution International License (CC BY 4.0).

http://creativecommons.org/licenses/by/4.0/

\section{(c) (i) Open Access}

\begin{abstract}
The study examined the specific factors that influence management share holdings and how this impact on the value of the firm in Ghana. The study specifically sought to find the relationship existing between managerial ownership and firm worth, non-linear relationship between managerial ownership and firm value, how managerial ownership and firm value are affected by size of firm and firm growth opportunities. Using secondary data from Ghana Stock Exchange from the period of 2015 to 2019, ten financial institutions (Banks) and ten non-financial institutions (non-bank) were purposively selected for the study, considering data availability and accessibility. Inferential statistics was adopted in analysing the data collected. The study found a weak positive linear relationship between firm worth and management's share holdings in the organization. The findings from the second research question revealed that the nature of the bond between management share holdings and firm value was the fact that it was nonlinear, however with no visible description of shape but rather fluctuating in nature. The study further found that there is a moderately weak positive association between firm worth and management share of holdings of the organization in the presence of firm size. The findings from the final research questions also revealed that connection between firm value and management holding of share is influenced by firm growth opportunities. The study recommends the development of a more robust and parsimonious model in the examination of the association between management ownership share and firm size to help improve on the strength and nature of the relationship as was revealed by weak correlation and coefficient of determination values.
\end{abstract}

\section{Keywords}

Management Share Ownership, Firm Value, Firm Growth Opportunities, Linear and Non-Linear Relationship 


\section{Introduction}

\subsection{Background to the Study}

A few examinations speculate a connection between the board's possession and firm qualities, especially when assessing firms' value. Offer ownership alludes to offers in an organization. As a result, a firm value has remained the point of interest of companies or firms, particularly in meeting the objectives of such companies of expanding the estimation of the firm or investors' worth, boosting benefits, and just limiting expenses, it is necessary for each organization to evaluate its monetary presentation or value and make it accessible to the clients, owners, shareholders, or partners of the organization. The value of the firm assists in determining the overall health over a specified time and can be used to compare firms in a similar industry or to analyze entire ventures or areas. The value of the firm can be assessed in a variety of ways, with one of the most common being the use of budgetary proportions. They are valuable indicators of a business's exhibition and financial situation. Regardless of this, it provides a connection that reveals information about an organization's operations, for example, the ratio of an organization's current assets to its current liabilities or the ratio of its borrowers to its turnover.

However, the firm's excellent performance, which is a measure of the firm's value, mostly basically depends on the management of such firms. If these managers are also owners of such firms or are shareholders simultaneously, then an irreconcilable situation among managers and investors helps us remember the need for a suitable degree of administrative proprietorship that guarantees the board choices line up with the advantage of investors. Earlier research has exhibited a relationship between administrative proprietorship, budgetary decisions, and firm incentives in created markets. For instance, an analysis of the impact of managerial ownership of firm is evident in the structure of the capital decisions, utilizing cases of regular citizen-run recorded firms in 2002-2007 in China resulted in a drive for capital structure into a non-linear shape, yet with a contrary course to the state of administrative possession on firm worth. The aftereffects of synchronous relapses propose that administrative possession impacts capital structure, which thus, influences firm worth. Therefore, the impact of being owners of a firm and that of the firm worth necessitates specific study for corporate funds (Denis \& McConnell, 2003). It is commonly realized that the inclinations between firms and owners are not completely adjusted and are likely to result in organizational issues that decrease firm worth or value.

A series of papers examined corporate organization in developing (or progressing economy) markets, with an emphasis on company worth and ownership structure relationship (see Lemmon \& Lins, 2003; Wei, 2005). Most of these prior studies discovered a non-linear relationship between authoritative ownership, also known as managerial ownership, and strong impetus in an infinite number of developing markets, indicating that organizations and insiders can participate in reallocating the preferences of other financial specialists. Corpo- 
rate insiders in China's registered organizations usually control business by swaying votes in their favour, but also via non-monetary means, for example, employee utilization, the creation of organization space, and so forth. Numerous other research studies continue to demonstrate that management ownership influences corporate value because value held by the board of directors may motivate supervisors to make value or money-related decisions to their advantage or the advantage of investors, resulting in a decline, alternatively an addition to firm value (Morck et al., 1988; Morck \& Steier, 2007; McConnell \& Servaes, 1990; Short \& Keasey, 1999; De Miguel et al., 2004). Hence, the viability of businesses may be related to the degree of managers who are also owners of the company.

This study is necessitated by the fact that top managerial staff is seen as a powerful inward corporate administration instrument. The board's power ranges from directing administrative activities, deciding the level and structure of top administration remuneration, and supplanting inadequately performing directors. All examinations locate that poor firm exhibition improves the probability of an adjustment in the top supervisory group. Weisbach (1988) reports that this outcome is available for firms with a board ruled by outside executives and credits this to fruitful checking by external chiefs. Nonetheless, the connection between firm execution and board turnover is genuinely feeble. It has driven a few creators, including (Jensen \& Murphy, 1990; Hermalin \& Weisbach, 1988), to scrutinize its monetary noteworthiness.

These investigations reflected across-the-board disappointment with balanced specialized ways to deal with essential leadership, arranging, and execution. Today, there are many issues going up against the board share proprietorship and firm worth, and a portion of the difficulties are different administration styles, personal propensities, financial matters and value, commitment levels, and disparities in aptitudes and jobs. These challenges and attributes on the part of the board and management can work in favour or to the company's disadvantage about their firm value. According to Assibey-Yeboah (2017), on the banking sector crisis in Ghana, fit owners either loaned to themselves, relatives, or family and friends, among others, resulting in most firms in an insolvency situation. This, therefore, becomes the directional line that this study shall attempt to address. This paper is divided into five parts. This article begins with an introduction part that gives context for the research subject and the study's shortcomings. Section 2 examines the literature on management share proprietory and firm value and its peculiar determinants. Section 3 covers the research methodology whereas Section 4 presents the data analysis results. Finally, Section 5 discusses the paper's findings, ramifications, and future research issues, thus completing the paper's goal.

\subsection{Significance of the Study}

This part of the paper is tailored to help us gain knowledge as to the extent in 
which this thesis is going to be beneficial to the society and the country at large. This include; helping to resolve the issues managers have about shareholders and also help to eradicate wrong perceptions about shareholders in the society; helping investigate more and know the effect of shareholders to the firm; aiding managers in making informed decisions as to who to share ownership and firm value with; contributing to improve future studies on management share ownership and firm value and assisting society to be aware of the kind of the firm they need to buy shares from.

\section{Review of Related Literature}

\subsection{Managerial Ownership}

Managerial ownership of a portion of the company's capital, or a group of workers, would undoubtedly enhance the interests of their profits while lowering agency expenses. As a result, Bekiris (2013) and Cziraki, Renneboog and Szilagyi (2010) emphasize that when managerial ownership reaches a high level, the agency problem is primarily mitigated due to complete alignment between managers and shareholders, with the result that the higher managerial ownership is, the less shareholder activism there is.

\subsection{Firm Size/Worth and Ownership}

The association between corporate governance and institutional investors has garnered considerable attention in the literature. Aggarwal, Erel, Ferreira and Matos (2011) found that institutional ownership significantly contributes to upholding good corporate governance. On the other hand, Bushee, Carter and Gerakos (2010) showed that appropriation by responsive governance institutions in the United States is associated with potential enhancements in shareholder rights. According to Chung and Zhang (2011), institutions' percentage of business shares seems to grow significantly in lockstep with quality of governance. Likewise, McCahery et al. (2016) discovered that institutional investors place a premium on corporate governance and that many are ready to participate in shareholder activism. The empirical research in this field shows that activism contributes to creating additional value if the goal is big. Cai and Walkling (2011) and Renneboog and Szilagyi (2011) have hypothesized that activist shareholders are more inclined to target big companies. Indeed, funds often believe that activism valuation is more straightforward in big businesses.

\subsection{Firm Growth and Performance}

According to Sahut and Othmani Gharbi (2011), this beneficial effect on company performance is consistent with institutional investors, especially dynamic behavior. On the other hand, many other writers have shown a detrimental impact of institutional investors on company performance. Huynh (2010) and Gantchev, Gredil and Jotikasthira (2015) expanded on the lack of a connection 
between company performance and shareholder interest. Hadani et al. (2011) and Goranova et al. (2017) investigated the connection between shareholders' proposals, earnings management, and institutional growth as measured by the book to market ratio. They found that low corporate growth encourages shareholders to compel leaders in such a situation.

\subsection{Linear Interaction of Firm Worth and Managerial Proprietorship}

Empirically, Ruan, Tian and Ma (2011) investigate the effect of management ownership on company performance via determinants of capital structure, using a population of China's civilian-run companies publicly traded on the Chinese stock market between 2002 and 2007. The findings demonstrated that the link between management ownership and company value is non-linear. Managerial ownership shapes the capital structure nonlinearly but in the opposite direction of its impact on company value. Simultaneous regressions indicate that organizational ownership influences capital structure, which subsequently influences company value. Further results suggest that the "interest convergence" and "entrenchment" impacts of managers' behaviour in terms of managerial ownership may also account for China's civilian-run companies' agency-related predicament. According to Sahut and Gharbi (2011), such individuals would seem to have a remarkably beneficial effect on company performance if they exhibited especially active corporate behavior. As a result, the greater their capital share, the more engaged they seem to be. This path seems to be worth pursuing. Ryu and Yoo (2011) address a long-standing debate about the relationship between managerial ownership and company value. They estimate ownership and control rights for each business group associated company using the Korean panel data. The metrics are distinct from Korean companies in Baek et al. (2004) or Joh (2003). Rather than confusing the two opposing effects, this article independently examines the convergence of interest and entrenchment hypotheses. Empirical findings indicate that, given control rights, there is no clear relationship between firm value and inside management ownership for the majority of firms with less than 42 percent inside management ownership, that a positive relationship exists between firm value and inside management ownership for those firms with more than 42 percent inside management ownership, and that, given owner control rights, there is a positive relationship between firm value and inside management ownership.

\subsection{Non-Linear Interaction of Firm Worth and Managerial Proprietary}

Ekadjaja et al. (2019) examine the ownership structure of a company, including managerial ownership, institutional ownership, foreign ownership, and concentrated ownership, as a predictor of firm value. Management ownership will be identified and studied for its potential to create an inverted U-shape relationship 
pattern, allowing for the parabolic impact of managerial ownership to be tested using Tobin's Q. Meanwhile, this kind of test cannot be performed on the other three independent variables. This test was conducted on non-financial listed companies that had their shares on the Indonesian Stock Exchange (IDX) from 2000 to 2017. The panel data regression test results indicate that management ownership can predict company value, while institutional and foreign ownership cannot.

Indrarini, Chandrarin and Subiyantoro (2019) access investors' perceptions of a company's degree of performance, which is often correlated with market prices. A rise in share prices indicates an increase in shareholder wealth. Specifically, the study examines the direct and indirect impacts of management ownership on the predictability of profits and company value. Between 2011 and 2016, the population consisted of all manufacturing firms registered on the Indonesian Stock Exchange. The SEM-PLS model was used to evaluate the data. Managerial ownership has a significant impact on earnings predictability, which is a proxy for profits quality. The predictability of earnings has a significant impact on company value. Managerial ownership significantly affects company value, both directly and indirectly, via the predictability of profits.

Mandaci and Gumus (2011) investigate the impact of ownership concentration and managerial ownership on the profitability and valuation of non-financial companies listed on the Istanbul Stock Exchange (ISE) in an emerging market environment. Firm's performance was evaluated using the Return on Assets (ROA) and Tobin's $\mathrm{Q}$ ratios, the former of which evaluates profitability, and the latter assesses the firm's worth. Additionally, we provide comprehensive information on the primary features of the ownership structures of the businesses in our sample and discover that Turkish firms are highly concentrated in ownership. Additionally, unlisted holding companies have the most significant average proportion of shares, corroborating the notion that individuals or families create holding companies to manage their publicly traded businesses. After adjusting for investment intensity, leverage, growth, and size, we show that ownership concentration has a statistically significant positive impact on company value and profitability. In contrast, managerial ownership has a statistically significant negative effect on firm value.

\subsection{Effect of Firm Size on Management Share Holdings and Firm Value}

According to Fahlenbrach, Prilmeier and Stulz (2018), from 1988 to 2003, the average change in managerial ownership was significantly negative for American firms, with managers more likely to decrease ownership when their firms are doing well and increasing ownership when their firms are struggling financially. Increasing management ownership raises Tobin's q when previous stock returns are controlled. Officers' shareholding increases drive this finding, whereas director shareholding increases seem unrelated to company value changes. There 
is little evidence that substantial ownership reductions harm company value. We use the managerial ownership or firm value relation's dynamics to address endogeneity issues.

According to Mandaci and Gumus (2011), the profitability and value of nonfinancial companies listed on the Istanbul Stock Exchange (ISE) are affected by ownership concentration and management ownership. Return on Assets (ROA) and Tobin's $Q$ ratios are used to assess the firm's performance. The study also provides comprehensive information on the ownership arrangements of the sample companies, revealing a highly concentrated ownership structure in Turkey. It is also believed that individuals or families set up unlisted holding corporations to control their listed businesses. After adjusting for investment intensity, leverage, growth, and size, it was found that ownership concentration increases firm value and profitability, whereas managerial ownership decreases both.

\subsection{Does Firm Growth Opportunity Influence Management Share Holding and Firm Value?}

Sakawa and Watanabel (2020) examine the role of institutional investors in a stakeholder-centred economy using data from 2924 Japanese firms from 20102016. The monitoring role of institutional shareholders, or foreign shareholders, functions well in Japanese corporations, and the monitoring roles are aimed at strengthening firms via higher growth opportunities. In a stakeholder-oriented structure, institutional shareholders help improve company performance and build sustainable corporate governance systems. Shan (2019) tests the bi-directional relationships using 9302 firm-year observations of Australian listed companies from 2005-2015 and a 3SLS (Three-Stage Least Squares) simultaneous equation model. Furthermore, Zondi and Sibanda (2015) use regression analysis to examine a link between managerial ownership and company performance in a sample of 23 retail sector companies listed on the JSE from 2010 to 2013. The findings are robust. The results show that there is a negative connection between management ownership and performance. A study using two-stage least squares (2SLS) finds that management ownership does not affect company performance. Also, Sualehkhattak and Hussain (2017) investigate the relationship between leverage, dividend payout ownership structure, and firm value using correlation analysis and ordinary least square (OLS) regression analysis on 148 non-financial companies listed on the Karachi Stock Exchange (KSE) for five years (20112015). Testing for panel data regressions. The study found a significant positive relationship between leverage and firm worth and a significant negative relationship between dividend payout and firm value. The interaction between leverage and growth opportunities is insignificant the connection between leverage, dividend payment, and ownership structure with business development possibilities. Based upon the extensive review of literature from variety of scholar in management share ownership and firm value, the basic premise has been estab- 
lished for this study to be conducted focusing on the developing country such as Ghana where not much studies have been conducted. Hence the need for this study considering the limitations, significance and gaps necessitated the study.

\section{Materials and Methods}

It fundamentally covers the type and source of data, econometric model, or method of data analysis, and issues of validity and reliability using model adequacy checking.

\subsection{Data Collection}

The study utilized secondary data, which is data acquired for a purpose other than the original reason it was collected. The data for this research came from non-financial organizations listed on the Ghana Stock Exchange (GSE). The market value of equity-to-book value of equity and the log of market capitalization was gathered during five years from 2015 to 2019. This period was chosen for the study because of the unavailability of data for the recent year. A gap between the time accounts is published, and the information in the accounts deemed surfacing on the market is likely to occur (Bokpin, 2013). Ten banks and ten non-banks were chosen from 100 business entities for the research based on data availability. Only non-financial companies are excluded from evaluating the management of closely regulated, highly geared firms because these traits have been shown to affect governance processes (Ntim et al., 2012).

\subsection{Econometric Modelling of Data}

Descriptive and inferential statistics were performed in the analysis of the data gathered for the study. The descriptive data analysis involved frequency tables and charts to help identify trends patterns of the main variables relating to firm value and managerial ownership over a period. Summary measures such as means, standard deviations, maximum and minimum values, and the range were computed. Inferential analysis, on the other hand, adopted the regression and correlation with analysis of variance to test hypothesis was employed to further corroborate the results from the descriptive statistics.

The critical variable is management share ownership. Control variables are added in the model to account for variation in firm value not attributable to management share ownership and to address endogeneity caused by an omitted variable. Per previous research, the study considers government ownership, the age of the firm's listing, its size, debt, and return on equity. Numerous arguments and empirical data support the assertion that these factors exhibit both linear and non-linear correlations with company value (Fiador, 2013). The assumption here is that firm value will be different across industries and financial years-accordingly, an inclusion of industry dummies (INDUST) for the two sectors, namely mining and pharmaceuticals. Also, year dummies (YD) for the financial years 2015 to 2019 are included. These variables are included to unveil 
unobservable effects such as trend effects and industry-specific effects.

$$
y_{i t}=\delta+\theta_{1} \text { MANSHARE }_{i t}+\beta^{\prime} X_{i t}+\lambda_{i}+\varepsilon_{i t}
$$

$i=1,2,3, \ldots, N$ is the cross-sectional dimension of companies, $t=1,2,3$, management share ownership (MANSHARE) is the independent variable, $X_{i t}$ is the set of control variables, $\lambda_{i}$ represents the unobserved firm-specific fixed effect, $\varepsilon_{i t}$ is the error term and $y_{i t}$ denote the dependent variable.

Where FV = Firm value is assessed in five ways: year-end share price, 3 month and 6 months share price, market-to-book value of equity, and market capitalization. MANSHARE = percentage of ordinary shares owned by directors at year-end. GOVSHARES = percentage of ordinary shares owned by the government and its institutions. LISTINGAGE = number of years a company has been listed on the GSE. Total assets at year-end FSIZE = natural log of book value $L E V=$ total liabilities/total assets in the year-end book value of equity, $R O E=$ earnings after tax and any preferential dividends. The STATA, together with EXCEL worksheet, were used in the data.

\subsection{Model Adequacy Checking}

In each study, the proper modelling technique is to verify the model by analysing the residuals using different diagnostic tests. These characteristics include multicollinearity, autocorrelation, heteroscedasticity, normalcy, and linearity. To test for multicollinearity, the research employs both Pearson pairwise and Spearman rank correlation coefficients. Additionally, the research examined for endogeneity. The existence of endogeneity is determined using the Durbin-Wu-Hausman homogeneity test, which determines if the coefficient of board share ownership is statistically significant for all firm value proxies.

\section{Results and Discussions}

This part of the paper deals with the analysis of data results in presentation and discussions is very crucial arriving at the conclusion of the study based on the methodology that was adopted for the study. The presentation in this section is systematically based on the objectives of the study which include: to investigate the relationship between managerial ownership and firm value; to examine whether the relationship between managerial ownership and firm value is nonlinear; to examine if the relationship between managerial ownership and firm value is influenced by the size of the firm, and to investigate if the relationship between managerial ownership and firm value is dependent on firm growth opportunities. Finally, it is essential to emphasis as per the data analysis method contained in the methodology that both the descriptive and inferential analysis were adopted in the analysis, presentation, and discussion of the results.

\subsection{Descriptive Statistics of Data}

Four main variables were involved in the study which include FV, MANSHARE, FGO, and size, where the acronyms connote their usual original meanings. The 
various descriptive statistics ranging from measure of location measures of dispersion such as the mean, median, mode; measures of variation such the standard deviation, sample variance, errors, the counts have been assessed with respect to the variables. This is to give a brief description of associated measurements of the variables and in particular identification and detection of missing values, or influential observations that can have any kind of effect on the analysis of the data. The results are summarized in the Table 1.

\subsection{Empirical Results of Key Findings}

To test for multicollinearity, the research employs both Pearson pairwise and Spearman rank correlation coefficients. The exact results for the multi-collinearity test are contained in Table 2 and discussed as follows.

The essence of the Pearson pairwise correlations is to find out if the variables are correlated, in other words if there exist a significant relationship between the independent variables including the control variables so as not to violate the principle of multi-collinearity. The diagonals have correlation coefficient of one, indicating perfect relationship. This also is because it represents the correlations

Table 1. Comparative descriptive statistics of variables of the study.

\begin{tabular}{ccccc}
\hline Statistic & FV & MANSHARE & FGO & SIZE \\
\hline Mean & 17.281 & 0.044 & 0.299 & 16.989 \\
Std Error & 0.129 & 0.007 & 0.047 & 0.141 \\
Median & 17.687 & 0.000 & 0.200 & 16.985 \\
Mode & 14.093 & 0.000 & 0.400 & - \\
Std Deviation & 2.086 & 0.109 & 0.756 & 2.275 \\
Sample Variance & 4.350 & 0.012 & 0.571 & 5.174 \\
Range & 8.282 & 0.467 & 10.300 & 11.711 \\
Minimum & 12.987 & 0.000 & -0.840 & 11.758 \\
Maximum & 21.269 & 0.467 & 9.460 & 23.470 \\
Sum & 4493.025 & 11.384 & 77.690 & 4417.150 \\
Observations & 260 & 260 & 260 & 260 \\
\hline
\end{tabular}

Source: Author's Computation, 2021.

Table 2. Multicollinearity of Firm Value (FV), Managerial Ownership Share (MANSHARE), Firm Growth Opportunities (FGO) and Firm Size (SIZE)

\begin{tabular}{ccccc}
\hline VALUE & FV & MANSHARE & FGO & SIZE \\
\hline FV & 1 & & & \\
MANSHARE & -0.206388 & 1 & & \\
FGO & 0.152903 & -0.072924425 & 1 & \\
SIZE & -0.135328 & -0.187199173 & 0.118487 & 1 \\
\hline
\end{tabular}

Source: Author's Computation, 2021. 
of each variable relating to its own self. Since the dependent variable is firm value (FV), its correlation with the reaming variables, that is managerial ownership share (MANSHARE) which is the independent variable, and as well as the control variables, that is firm growth opportunities (FGO), and firm size (size) was not important. It can be seen from the results that the correlations among the dependent and the control variables were very small, though not zero with the highest being -0.187 for the relationship between size and MANSHARE. It therefore implies the absence of multi-collinearity in the data as far as the independent and the control variables were concerned. This further indicates that the data is suitable for such analysis based on the methodological approach.

The results of the objective have been presented in the Table 3 and Table 4 using regression and correlation techniques and discussed as follows.

The test of the relationship between managerial ownership shares and firm value indicated the existence of a relationship and subsequent confirmation of the statistical significance of the existence of such a relationship, it is appropriate to model the relationship by way of an appropriate equation that will be able to generate estimates and forecasts. Therefore, model is thus given as $Y=17.453-$ $3.93431 X$, where $Y$ is the firm value, and $X$ being the management ownership share. The constant value of 17.453 is or will be the initial value firm value when management ownership share is set to zero (0), whilst the -0.9343 is the magnitude of change in the firm value because of a change in management ownership share.

Table 3. Link between management share holding and firm worth.

\begin{tabular}{ccccc}
\hline & Coefficient & Std. Error & T-Statistic & $p$-value \\
\hline Intercept & 17.453 & 0.137 & 127.753 & $3 \mathrm{E}-235$ \\
MANSHARE & -3.934 & 1.161 & -3.388 & 0.000814 \\
R & 0.206 & & & \\
R Square & 0.043 & & \\
Adjusted R Square & 0.039 & & \\
Standard Error & 2.045 & & \\
Observations & 260 & & \\
\hline
\end{tabular}

Source: Author’s Computation, 2021; ${ }^{\star} p 0.05$ significant ${ }^{\star}$.

Table 4. Analysis of Variance (ANOVA) of the link between management share holding and firm value.

\begin{tabular}{ccccc}
\hline Source of variation & df & SS & MS & Significance F \\
\hline Regression & 1 & 47.987 & 47.987 & 0.000 \\
Residual & 258 & 1078.576 & 4.181 & \\
Total & 259 & 1126.563 & & \\
\hline
\end{tabular}

Source: Author's Computation, 2021; ${ }^{\star} p 0.05$ significant ${ }^{\star}$. 
The probability $(p)$ value indicates a statistical significance at a significance level of 0.05 since the $p$-value of 0.0008 is less that the level of significance. This further corroborates the earlier conclusion of the statistical significance of the relationship in overall terms using the analysis of variance tests and the parameter tests as well. This is result is consistent with the proposition that increasing management share affects the interest of minority shareholders, but also provides support for the results of past studies that report a negative coefficient of board share ownership on firm value (Ruan, Tian, \& Ma, 2011; Sahut \& Gharbi, 2011) and inconsistent with past studies that report a positive coefficient between share of ownership and firm value. This implies that the model thus obtained based on the relationship between management share of ownership can be used to predict firm value especially in the absence of a better model in this context.

The analysis' model summary is used to determine the type, strength, and margin of variability of the estimate in terms of the connection between managerial share ownership and company value. Since the correlation coefficient is not zero (0), it indicates that there is a connection between company value and management ownership share. Correlation coefficient (R) of 0.206 indicates a somewhat favorable relationship between company value and management portion of ownership. Its positive sign also implies that when management owns a stake in the business, it weakly increases the firm's value, implying that management share ownership as a governance mechanism has been a boon to the emerging capital market, as the level of management share ownership increases, the market value of the firm increases. This finding contradicts the notion that growing management share ownership has a detrimental effect on minority shareholders' interests. Additionally, the result provides evidence to refute those whose evidence supports previous studies reporting a negative effect of board share ownership on firm value and is inconsistent with previous studies reporting a positive relationship between board share ownership and firm value, such as Arshad and Javid (2014), who find conclusive evidence that managerial ow The consequence of this finding for the Ghana stock market is that if management owns a portion of the company, it will have a somewhat favorable impact on the firm's valuation. Furthermore, the coefficient of determination ( $\mathrm{R}$ square) of 0.0425 (4.26 percent), which is a measure of the proportion of variation in the dependent variable that is explained by the independent variable, indicates that management share of ownership accounts for or explains only 4.26 percent of the change in firm value. This also implies that about 95.74 percent of the change in company value is not due to changes in management ownership but to other variables not considered in this study. This finding is similar with the findings of Aggarwal et al. (2011), who found that institutional ownership significantly aids in the maintenance of good corporate governance, which results in increased company value.

Table 4 uses a variance analysis to examine the connection between manage- 
ment share ownership and company value. The table shows that the connection is statistically significant since the $P$-value of 0.0008 is less than the significant threshold of 0.05 . In the absence of a better model for evaluating the connection between management share ownership and company value, the model should be kept even if the correlation and determination coefficients are lower. This conclusion is in line with previous research showing a strong link between board shareholding and company value (Connelly et al., 2012). According to this research and earlier studies, allowing managers to be part of the firm's shareholders increases the firm's worth by a statistically significant amount. Therefore, management must hold stock in the company to increase the firm's value, which is the main reason for its existence. A previous study used a simultaneous equation model to examine the effect of managerial ownership on firm performance and financial policies (debt and dividend) for 140 listed manufacturing firms in Pakistan (Arshad \& Javid, 2014).

Another important aspect was to examine whether the link between managerial ownership and firm worth is non-linear or otherwise. As a result, a graphical approach as depicted in Figure 1 is used to show the relationship between the two variables with firm value being the dependent variable and MANSHARE being the independent variable on the other hand. From the results in Figure 1, the association between managerial shares holding and firm worth was weak positive using the correlation coefficient and statistically significant but is negatively related in model and statistically significant using the regression coefficients. This result provides support the examination of the nature of the relationship as to whether it is non-linear. Based on the frequency curve used in assessing the nature of the bond, it can be seen clearly that the nature of the connection is non-linear. This again is consistent with past studies which reported a significant curvilinear association between board share ownership and firm value (Connelly et al., 2012). In the same vein therefore, it can be concluded that the link between management share ownership and firm value is non-linear. However, it is also important to emphasise that from previous studies which the non-linear nature of the association reflected a $u$ shape, that of the relationship between management ownership share and firm value display otherwise with no visible description of shape. The non-linear nature of the link between management share of ownership and firm value can either be describable or indescribable based on both the current and previous studies.

Next was to examine if the bond between managerial ownership and firm value is influenced by the size of the firm. This is explored to ascertain if the size of firm could be a useful control variable since the link between management ownership share and firm worth was only $0.206 \%$ and $4.6 \%$ for the correlation coefficient and the coefficient of determination respectively. This is further assessed using the same approach of regression with control variable as summarised in Table 5 and Table 6 as follows. 


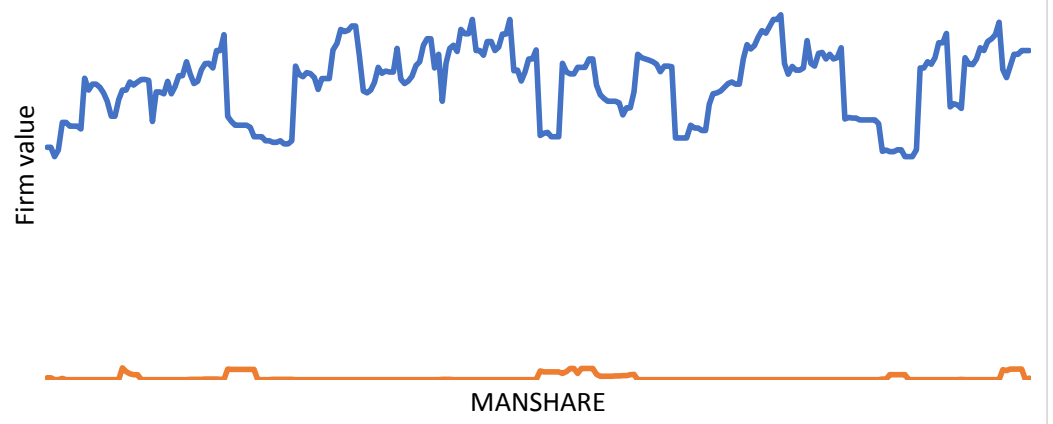

Figure 1. Frequency curve of the relationship between FV and MANSHARE.

Table 5. Effect of firm size on management share holding and firm value.

\begin{tabular}{ccccc}
\hline & Coefficient & Std. Error & T-Statistic & $p$-value \\
\hline Intercept & 20.290 & 0.971 & 20.900 & 0.000 \\
MANSHARE & -4.578 & 1.165 & -3.930 & 0.000 \\
SIZE & -0.165 & 0.056 & -2.950 & 0.003 \\
R & 0.272 & & & \\
R Square & 0.074 & & & \\
Adjusted R Square & 0.067 & & & \\
Standard Error & 2.015 & & & \\
Observations & 260 & & & \\
\hline
\end{tabular}

Source: Author's Computation, 2021; ${ }^{\star} p 0.05$ significant $^{\star}$.

Table 6. Analysis of Variance (ANOVA) of association between management share holding and firm value as influenced by firm size.

\begin{tabular}{ccccc}
\hline Source of variation & df & SS & MS & Significance F \\
\hline Regression & 2 & 83.319 & 41.660 & 0.000 \\
Residual & 257 & 1043.244 & 4.059 & \\
Total & 259 & 1126.563 & & \\
\hline
\end{tabular}

Source: Author's Computation, $2021 ;{ }^{\star} p 0.05$ significant $^{\star}$.

With regard the model as based the association between managerial ownership of share and firm value with size of firm as the control variable is given as $Y$ $=20.289-4.5776 X_{1}-0.1653 X_{2}$, where $Y$ is the firm value, and $X_{1}$ and $X_{2}$ representing management ownership share and size of firm respectively. The constant value of 20.289 represents the initial value of firm value when management ownership share, and size of firm are absent. The values of -4.577 and -0.165 represent the respective values of the magnitude of change in firm value because of a unit change in management ownership share and size of firm respectively. The probability $(p)$ values further indicate a statistical significance at a significance level of 0.05 since the $p$-value of 0.0001 and 0.003 are both less 
than the level of significance. This further corroborates the earlier conclusion of the statistical significance of the relationship in overall terms using the analysis of variance tests and the parameter tests as well.

Table 4 uses a variance analysis to examine the connection between management share ownership and company value. The table shows that the connection is statistically significant since the $p$-value of 0.0008 is less than the significant threshold of 0.05 . In the absence of a better model for evaluating the connection between management share ownership and company value, the model should be kept even if the correlation and determination coefficients are lower. This conclusion is in line with previous research showing a strong link between board shareholding and company value (Connelly et al., 2012). According to this research and earlier studies, allowing managers to be part of the firm's shareholders increases the firm's worth by a statistically significant amount. Therefore, management must hold stock in the company to increase the firm's value, which is the main reason for its existence. A previous study used a simultaneous equation model to examine the effect of managerial ownership on firm performance and financial policies (debt and dividend) for 140 listed manufacturing firms in Pakistan (Arshad \& Javid, 2014).

Again, the coefficient of determination (R square) of value 0.074 (7.4\%) indicate that $7.4 \%$ of the proportion of variation in the firm value is accounted for or explained by both management ownership shares and size of firm. This further indicate that about $92.6 \%$ of the changes in firm value is not accounted for by management share of ownership and firm size but rather by other factors which have not been included in this analysis. This result is consistent with Aggarwal, et al. (2011) who discovered that institutional ownership helps greatly in maintaining effective corporate governance which then leads to higher firm value. It follows from the result above that the introduction of the firm size as a control variable did not necessarily influence upward adjustment in the firm value based on managerial ownership. Rather managerial ownership alone as an explanatory or independent variable had a great influence on firm value. Al-Gharaibeh et al. (2013) tried to examine the impact of ownership structure on corporation dividend policy using a sample of 35 Jordanian corporations listed on the Amman Stock Exchange between 2005 and 2010. The complete adjustment model described 61.57 percent of the variance in dividend, whereas the partial adjustment model explained just 20.65 percent. For management ownership, the partial adjustment model yielded a negative but significant coefficient, while the complete adjustment model yielded a Thus, evaluating managerial ownership share on every element of the business led to an upward rise, highlighting managerial ownership share's significant contribution to the firm.

Based on the test of significance of the relationship as contained in the ANOVA, Table 6 shows that the relationship between management share ownership and firm value as influenced by firm size at a significant level of 0.05 . This implies that the model should be maintained in the absence of a better model for ex- 
amining the relationship between managerial share ownership and firm value as influenced by firm size.

The study further investigates if the relationship between managerial ownership and firm value is dependent on firm growth opportunities. In other words, if firm growth opportunities (FGO) influence the relationship between firm value and management ownership share. Table 7 and Table 8 summarise the results of the various relationships as discussed as follows.

With regard the model as based the association between managerial ownership share and firm value with firm growth opportunities as the control variable is given as $Y=17.330-3.74165 X_{1}+0.38235 X_{2}$, where $Y$ is the firm value, and $X_{1}$ and $X_{2}$ representing management ownership share and firm growth opportunities respectively. About the coefficients in the model, the constant value of 17.330 represent the initial value of firm value when management ownership shares and firm growth opportunities are absent, all other factors held constant. The values of -3.7416 and 0.3823 represent the respective values of the magnitude of change in firm value because of a unit change in management ownership share and firm growth opportunities respectively. The probability $(p)$ values again indicate a statistical significance at a significance level of 0.05 since the $p$-value of 0.001 and 0.023 are both less than the level of significance. This further corroborates the earlier conclusion of the statistical significance of the relationship in overall terms using the analysis of variance tests and the parameter tests as well.

Table 7. The effect of growth opportunities on management share holding and firm value.

\begin{tabular}{ccccc}
\hline & Coefficient & Std. Error & T-Statistic & $p$-value \\
\hline Intercept & 17.330 & 0.146 & 118.916 & 0.000 \\
MANSHARE & -3.742 & 1.155 & -3.240 & 0.001 \\
FGO & 0.382 & 0.167 & 2.288 & 0.022 \\
R & 0.248 & & & \\
R Square & 0.062 & & & \\
Adjusted R Square & 0.054 & & & \\
Standard Error & 2.028 & & \\
Observations & 260 & & \\
\hline
\end{tabular}

Source: Author's Computation, 2021; ${ }^{\star} p 0.05$ significant $^{\star}$.

Table 8. Analysis of Variance (ANOVA) of connection between management share holding and firm value as influenced by firm size.

\begin{tabular}{ccccc}
\hline Source of variation & df & SS & MS & Significance F \\
\hline Regression & 2 & 69.510 & 34.755 & 0.000 \\
Residual & 257 & 1057.053 & 4.113 & \\
Total & 259 & 1126.563 & & \\
\hline
\end{tabular}

Source: Author's Computation, $2021 ;{ }^{\star} p 0.05$ significant ${ }^{\star}$. 
From the model summary Table 7, the correlation coefficient (R) of 0.248 indicate a moderately weak positive association between firm value and management share of ownership in the presence of firm growth opportunities. It increases the correlation coefficient from 0.206 to 0.248 . This implies that the relationship between firm value and management ownership share is influenced by firm growth opportunities. This further implies that an assessment of the relationship between firm value and management ownership share should be done with the inclusion of firm growth opportunities.

Because the R square is 0.061 (6.1\%), both management ownership shares and firm development possibilities account for or explain $6.1 \%$ of the variance in firm value, suggesting that 93.9 percent of the variation in company value is not jointly accounted for or explained. However, the modest influence of managerial ownership on firm value is consistent with earlier findings that expansion has a favorable impact on managerial ownership. Theoretically, expansion should increase management ownership. It shows that managers favor investing in fastgrowing companies (Din \& Javid, 2011). Using another variable as a control variable in assessing the impact of management share of ownership on firm value yielded a moderate or weak positive influence on firm value while yielding a negative coefficient. As previously reported, board share ownership has a negative impact on company value, while management share ownership has a favourable impact.

Based on the test of significance of the relationship as contained in the ANOVA Table 8 shows that the relationship between management share ownership and firm value as influenced by firm growth opportunities is significant at 0.05 level of significance, and as a result model can be maintained in the absence of a better model for examining the relationship between managerial share ownership and firm value as influenced by firm growth opportunities.

\section{Conclusion}

To begin, all four (4) variables included in the study, namely firm value (FV), management ownership share (MANSHARE), firm growth opportunities (FGO), and firm size (size), were relevant because they aided in measuring what the study intended to measure in terms of the assessment of emerging market capital markets via descriptive statistics such as mean, median, and mode. Additionally, regarding the study's first aim, which was to examine the connection between managerial ownership and company value, the findings indicated the presence of a relationship between firm value and managerial ownership share. Thus, the study concludes that the relationship was weak regardless of sign and could only account for 4.26 percent of the changes in the dependent variable, with approximately 95.74 percent of the change in firm value as per the data and analysis performed being accounted for by factors other than management share of ownership. Additionally, the research finds that when the connection between managerial ownership and firm value is examined as a function of company size, 
a substantial association exists between management ownership share and firm value as a function of firm size. Thus, about 92.6 percent of the changes in company value were accounted for by variables other than management ownership share and firm size. The conclusion related to the final objective, which was to determine whether the relationship between managerial ownership and firm value is dependent on firm growth opportunities, is that in the presence of firm growth opportunities, a moderately weak positive association between firm value and management share of ownership was also observed.

\section{Recommendations}

The following suggestions are offered considering the study's results and conclusions. The research suggests developing a more robust and sparser model to examine the connection between management ownership share and company size to enhance the strength and nature of the association as indicated by low correlation and coefficient of determination values. Second, the research proposes a more robust connection by expanding the data or changing the variables to clearly demonstrate the non-linear or otherwise nature of the link between management ownership and company value. Additionally, it is recommended that additional control variables be included in the model, as only the firm's size as a control variable revealed a significant relationship between management ownership share and firm value, resulting in a model that fully explains the dynamics of the relationship between firm size and management ownership share for prudent decision making. Finally, and similarly to the conclusion about the goal, it is suggested that the connection between management ownership and company value be remodelled to include other control factors in addition to firm development possibilities. This is because the two (2) control variables added to the model improved or enhanced the values of the model coefficients, resulting in a more accurate model than the models without control variables.

\section{Conflicts of Interest}

The authors declare no conflicts of interest regarding the publication of this paper.

\section{References}

Aggarwal, R., Erel, I., Ferreira, M., \& Matos, P. (2011). Does Governance Travel around the World? Evidence from Institutional Investors. Journal of Financial Economics, 100, 154-181. https://doi.org/10.1016/j.jfineco.2010.10.018

Al-Gharaibeh, M., Zurigat, Z., \& Al-Harahsheh, K. (2013). The Effect of Ownership Structure on Dividends Policy in Jordanian Companies. Interdisciplinary Journal of Contemporary Research in Business, 4, 769-796.

Arshad, H., \& Javid, A. Y. (2014). Does Inside Ownership Matters in Financial Decisions and Firm Performance: Evidence from Manufacturing Sector of Pakistan. PIDE Working Papers, 1, 1-39.

Assibey-Yeboah, F. (2017). Report of the Finance Committee on a Referral by the House 
to Inquire into Measures Put in Place by Bank of Ghana to Improve the Activities of Microfinance Companies and Check the Operations of Sham Companies in the Country.

Baek, J. S., Kang, J. K., \& Park, K. S. (2004). Corporate Governance and Firm Value: Evidence from the Korean Financial Crisis. Journal of Financial Economics, 71, 265-313. https://doi.org/10.1016/S0304-405X(03)00167-3

Bekiris, F. V. (2013). Ownership Structure and Board Structure: Are Corporate Governance Mechanisms Interrelated? Corporate Governance, 13, 352-364. https://doi.org/10.1108/CG-02-2011-0013

Bokpin, G. A. (2013). Ownership Structure, Corporate Governance and Bank Efficiency: An Empirical Analysis of Panel Data from the Banking Industry in Ghana. Corporate Governance, 13, 274-278. https://doi.org/10.1108/CG-05-2010-0041

Bushee, B. J., Carter, M. E., \& Gerakos, J. J. (2010). Institutional Investor Preferences for Corporate Governance Mechanisms. SSRN eLibrary.

Cai, J., \& Walkling, R. A. (2011). Shareholders' Say on Pay: Does It Create Value? Journal of Financial and Quantitative Analysis, 46, 299-339.

Chung, K. H., \& Zhang, H. (2011). Corporate Governance and Institutional Ownership. Journal of Financial and Quantitative Analysis, 46, 247-273. https://doi.org/10.1017/S0022109010000682

Connelly, J. T., Limpaphayom, P., \& Nagarajan, N. J. (2012). Form versus Substance: The Effect of Ownership Structure and Corporate Governance on Firm Value in Thailand. Journal of Banking \& Finance, 36, 1722-1743. https://doi.org/10.1016/j.jbankfin.2012.01.017

Cziraki, P., Renneboog, L., \& Szilagyi, P. G. (2010). Shareholder Activism through Proxy Proposals: The European Perspective. European Financial Management, 16, 738-777. https://doi.org/10.1111/j.1468-036X.2010.00559.x

De Miguel, A., Pindado, J., \& De la Torre, C. (2004). Ownership Structure and Firm Value: New Evidence from Spain. Strategic Management Journal, 25, 1199-1207. https://doi.org/10.1002/smj.430

Denis, D. K., \& McConnell, J. J. (2003). International Corporate Governance. Journal of Financial and Quantitative Analysis, 38, 1-36. https://doi.org/10.2307/4126762

Din, S. U., \& Javid, A. Y. (2011). Impact of Managerial Ownership on Financial Policies and the Firm's Performance: Evidence Pakistani Manufacturing Firms. International Research Journal of Finance and Economics, No. 81, 13-29.

Ekadjaja, M., Siswanto, H. P., Nuringsih, K., \& Amelinda, R. (2019). Parabolic Effect between Managerial Ownership and Firm Value to Control Agency Conflict. Jurnal Manajemen, 23, 355-374. https://doi.org/10.24912/jm.v23i3.569

Fahlenbrach, R., Prilmeier, R., \& Stulz, R. M. (2018). Why Does Fast Loan Growth Predict Poor Performance for Banks? The Review of Financial Studies, 31, 1014-1063. https://doi.org/10.1093/rfs/hhx109

Fiador, V. O. (2013). Corporate Governance and Value Relevance of Financial Information: Evidence from the Ghana Stock Exchange. Corporate Governance, 13, 208-217. https://doi.org/10.1108/14720701311316689

Gantchev, N., Gredil, O., \& Jotikasthira, C. (2015). Governance under the Gun: Spillover Effects of Hedge Fund Activism. European Corporate Governance Institute.

Goranova, M., Abouk, R., Nystrom, P. C., \& Soofi, E. S. (2017). Corporate Governance Antecedents to Shareholder Activism: A Zero-Inflated Process. Strategic Management 
Journal, 38, 415-435. https://doi.org/10.1002/smj.2472

Hadani, M., Goranova, M., \& Khan, R. (2011). Institutional Investors, Shareholder Activism, and Earnings Management. Journal of Business Research, 64, 1352-1360. https://doi.org/10.1016/j.jbusres.2010.12.004

Hermalin, B. E., \& Weisbach, M. S. (1988). The Determinants of Board Composition. The RAND Journal of Economics, 19, 589-606.

Huynh, K. P., \& Petrunia, R. J. (2010). Age Effects, Leverage and Firm Growth. Journal of Economic Dynamics and Control, 34, 1003-1013. https://doi.org/10.1016/j.jedc.2010.01.007

Indrarini, S., Chandrarin, G., \& Subiyantoro, E. (2019). Managerial Ownership, Earnings Predictability and Firm Value on Indonesia Stock Exchange. Managerial Ownership, Earnings Predictability and Firm Value on Indonesia Stock Exchange, 21, 39-46.

Jensen, M. C., \& Murphy, K. J. (1990). Performance Pay and Top-Management Incentives. Journal of Political Economy, 98, 225-264. https://doi.org/10.1086/261677

Joh, S. W. (2003). Corporate Governance and Firm Profitability: Evidence from Korea before the Economic Crisis. Journal of financial Economics, 68, 287-322. https://doi.org/10.1016/S0304-405X(03)00068-0

Lemmon, M. L., \& Lins, K. V. (2003). Ownership Structure, Corporate Governance, and Firm Value: Evidence from the East Asian Financial Crisis. The Journal of finance, 58, 1445-1468. https://doi.org/10.1111/1540-6261.00573

Mandac1, P. E., \& Gumus, G. K. (2011). Ownership Concentration, Managerial Ownership and Firm Performance: Evidence from Turkey. South East European Journal of Economics and Business, 5, 57-66. https://doi.org/10.2478/v10033-010-0005-4

McCahery, J. A., Sautner, Z., \& Starks, L. T. (2016). Behind the Scenes: The Corporate Governance Preferences of Institutional Investors. The Journal of Finance, 71, 29052932. https://doi.org/10.1111/jofi.12393

McConnell, J. J., \& Servaes, H. (1990). Additional Evidence on Equity Ownership and Corporate Value. Journal of Financial Economics, 27, 595-612. https://doi.org/10.1016/0304-405X(90)90069-C

Morck, R., Shleifer, A., \& Vishny, R. W. (1988). Management Ownership and Market Valuation: An Empirical Analysis. Journal of Financial Economics, 20, 293-315. https://doi.org/10.1016/0304-405X(88)90048-7

Morck, R. K., \& Steier, L. (2007). The Global History of Corporate Governance: An Introduction (pp. 1-64). University of Chicago Press.

Ntim, C. G., Opong, K. K., \& Danbolt, J. (2012). The Relative Value Relevance of Shareholder versus Stakeholder Corporate Governance Disclosure Policy Reforms in South Africa. Corporate Governance: An International Review, 20, 84-105. https://doi.org/10.1111/j.1467-8683.2011.00891.x

Renneboog, L., \& Szilagyi, P. G. (2011). The Role of Shareholder Proposals in Corporate Governance. Journal of Corporate Finance, 17, 167-188. https://doi.org/10.1016/j.jcorpfin.2010.10.002

Ruan, W., Tian, G., \& Ma, S. (2011). Managerial Ownership, Capital Structure and Firm Value: Evidence from China's Civilian-Run Firms. Australasian Accounting, Business and Finance Journal, 5, 73-92.

Ryu, K., \& Yoo, J. (2011). Relationship between Management Ownership and Firm Value among the Business Group Affiliated Firms in Korea. Journal of Comparative Economics, 39, 557-576. https://doi.org/10.1016/j.jce.2011.05.002 
Sahut, J.M., \& Gharbi, H.O. (2011). Influence of French and Foreign Institutional Shareholders on the Financial Performance of Firms. The Review of Management sciences, No. 5, 51-62.

Sakawa, H., \& Watanabel, N. (2020). Institutional Ownership and Firm Performance under Stakeholder-Oriented Corporate Governance. Sustainability, 12, Article No. 1021. https://doi.org/10.3390/su12031021

Shan, Y. G. (2019). Managerial Ownership, Board Independence and Firm Performance. Accounting Research Journal, 32, 203-220. https://doi.org/10.1108/ARJ-09-2017-0149

Short, H., \& Keasey, K. (1999). Managerial Ownership and the Performance of Firms: Evidence from the UK. Journal of Corporate Finance, 5, 79-101.

https://doi.org/10.1016/S0929-1199(98)00016-9

Sualehkhattak, M., \& Hussain, M. C. H. (2017). Do Growth Opportunities Influence the Relationship of Capital Structure, Dividend Policy and Ownership Structure with Firm Value: Empirical Evidence of KSE. Journal of Accounting and Marketing, 6, Article No. 216. https://doi.org/10.4172/2168-9601.1000216

Wei, Y. (2005). Volatility of China's Securities Markets and Corporate Governance. Suffolk Transnational Law Review, 29, 207.

Weisbach, M. S. (1988). Outside Directors and CEO Turnover. Journal of Financial Economics, 20, 431-460. https://doi.org/10.1016/0304-405X(88)90053-0

Zondi, S., \& Sibanda, M. (2015). Managerial Ownership and Firm Performance on Selected JSE Listed Firms. Corporate Ownership \& Control, 12, 233-241.

https://doi.org/10.22495/cocv12i3c2p3 